\title{
Rearing of White Leg Shrimp Litopenaeus vannamei (Boone, 1931) in Biofloc and Substrate Systems: Microbial Community of Water, Growth and Immune Response of Shrimp
}

\author{
Lavanya Chethurajupalli $^{1}\left(\mathbb{D}\right.$, Neeraja Tambireddy $^{1, *}$ (i)
}

${ }^{1}$ Sri Venkateswara Veterinary University, College of Fishery Science, Department of Aquatic Animal Health Management, Muthukur- 524344 Nellore, Andhra Pradesh, India.

\begin{abstract}
How to cite
Chethurajupalli, L., Tambireddy, N. (2022). Rearing of White Leg Shrimp Litopenaeus vannamei (Boone, 1931) in Biofloc and Substrate Systems: Microbial Community of Water, Growth and Immune Response of Shrimp. Turkish Journal of Fisheries and Aquatic Sciences, 22(3), TRJFAS20130. http://doi.org/10.4194/TRJFAS20130
\end{abstract}

\section{Article History}

Received 25 June 2021

Accepted 27 October 2021

First Online 03 November 2021

\section{Corresponding Author}

Tel.: +919866210891

E-mail: tambinee@yahoo.com

\section{Keywords}

Biofloc

Substrate

L. vannamei

Water quality

Immune response

\begin{abstract}
The microbial composition of rearing water, growth and immune status of Litopenaeus vannamei juveniles in biofloc (T1), substrate-integrated biofloc (T2), substrate (T3) systems and a control with four replicates each were evaluated in a 49-day indoor trail. In each HDPE tank of $70 \mathrm{~L}$ capacity filled with $10 \mathrm{~g} \mathrm{~L}^{-1}$ salinity water, ten shrimp $(4.56 \pm 0.13 \mathrm{~g})$ were stocked. The $\mathrm{C}$ : $\mathrm{N}$ ratio of $15: 1$ was maintained in $\mathrm{T} 1$ and $\mathrm{T} 2$ using wheat flour as carbon source for production of biofloc. The TAN, $\mathrm{NO}_{2}$ and $\mathrm{NO}_{3}$ were lower $(P<0.05)$ in treatment tanks than that in control. It was also observed that the counts of Bacillus, Lactobacillus, Vibrio and zooplankton were high in T2 than T1, T3 and control. There was higher net weight gain $(10.38 \pm 0.14 \mathrm{~g})$ and lowest FCR $(1.27 \pm 0.12)$ with $T 2$ when compared to $T 1, T 3$ and control tanks. Moreover, the survival rate is significantly higher in treatments than control. Significant increase in THC $\left(47.24 \pm 4.49 \times 10^{6}\right.$ cells $\left.\mathrm{ml}^{-1}\right)$, serum protein $(82.67 \pm 0.01 \mathrm{mg} / \mathrm{ml})$, Phenoloxidase $(0.73 \pm 0.03, \mathrm{OD} 490 \mathrm{~nm})$ and Lysozyme activity $(56.32 \pm 0.03 \%)$ was observed in $\mathrm{T} 2$ than T1, T3 and control. The result shows that substrate-integrated biofloc system assures higher growth, survival and better immune response in L. vannamei.
\end{abstract}

\section{Introduction}

Among the cultivable shrimps, the Pacific white shrimp LitopenFaeus vannamei has been farmed intensively in many parts of the world (FAO, 2012). The intensive shrimp rearing systems are using large volumes of water for exchange and excessive use of high protein feeds has caused adverse environmental impacts (Martinez-Porchas et al., 2012). Hence, emphasis should be given to produce high quality shrimp in an eco-friendly manner at relatively lower production cost. Therefore, industry needs to develop an alternative technique to the existing intensive culture systems. Biofloc technology (BFT) has been developed as an intensive rearing system to make shrimp farming more cost effective and eco-friendly by means of reduced water use and effluent discharges with improved biosecurity (Wasielesky et al., 2006; Khanjani and Sharifinia, 2020). Bioflocs are heterogeneous mixture of bacteria, filamentous microalgae, protozoans, rotifers, worms and nonliving components (Ju et al., 2008; Ballester et al., 2010; Galvez, 2015; Panigrahi et al., 2017; Manan et al., 2017). Bacterial populations such as Bacillus sp., Lactobacillus sp., and Vibrio sp., were reported in biofloc systems (Anand et al., 2014; Kumar et al., 2015), besides bioactive compounds like carotenoids (Xu \& Pan 2013) and were known for probiotic (Crab et al., 2010) and immunostimulant (Anguilera-Rivera et al., 2014) properties. In shrimp farming, bioflocs could reduce 
ammonia and nitrite in water (De Schryver et al., 2008; Ray et al., 2011; Xu et al., 2012a; Kamilya et al., 2017; Abbaszadeh et al., 2019; Khanjani et al., 2016, 2019); augment growth (Ballester et al., 2010; Emerenciano et al., 2012; Xu \& Pan 2012; Xu et al., 2012; Abbaszadeh et al., 2019) and non-specific immunity, there by enhanced protection from pathogenic bacteria (Smith et al., 2003; Vazquez et al., 2009; Ekasari et al., 2014). The bioflocs have 'natural probiotic' effect and it could act both internally and/or externally against to the Vibrio sp. in shrimp (Panigrahi et al., 2014). The microorganisms in the biofloc and their cellular material or cell metabolites could act as immunostimulators that can improve the innate immune system of shrimp and provide protection against the bacterial pathogens (Smith et al., 2003; Vazquez et al., 2009).

The use of submerged artificial substrates in biofloc system has been projected as another way to enhance production of shrimp, as the submerged substrates supply sites for the production of autotrophic and heterotrophic bacterial community which maintain quality of water and serve as natural food for culturing animals (Langis et al., 1988; Ramesh et al., 1999; Thompson et al., 2002; Panigrahi et al., 2017). In the submerged substrate-based culture system/periphytonbased culture system, periphyton or biofilm on substrate usually consists of microscopic organisms like algae, bacteria, fungi, protozoa, zooplankton, other invertebrates and detritus (Azim et al., 2001; Azim \& Wahab 2005; Anand et al., 2013). Periphyton developed on the submerged substrates can uptake nitrogenous compounds such as ammonia and nitrite, control the concentration of dissolved oxygen (DO) and maintain $\mathrm{pH}$ of the surrounding water (Azim et al., 2002; Dodds, 2003; Bender et al., 2004; Schveitzer et al., 2013; Anand et al., 2019; Shilta, et al., 2020).

Earlier studies on the effect of biofloc systems on water quality, growth, survival and production has been documented to some extent in tiger shrimp (Hargreaves 2013; Anand et al., 2014; Kumar et al., 2015), L. vannamei (Khanjani et al., 2016, 2019; Panigrahi et al., 2017, 2019; Abbaszadeh et al., 2019; Tong et al., 2020; Huang et al., 2021; Silva et al., 2021), Fenneropenaeus indicus (Effendy et al., 2016), Farfantepenaeus paulensis (Ballester et al., 2010) and Marsupenaeus japonicus (Zhao et al., 2012) and to a limited extent on physiological health status of $P$. monodon (Kumar et al., 2015) and L. vannamei (Xu \& Pan 2013; Panigrahi et al., 2017). Furthermore, the use of artificial substrates in shrimp culture has been studied only for the growth performance and water quality (Audelo-Naranjio et al., 2010; Zhang, 2011; Zhang et al., 2014; Anand et al., 2019; Shilta et al., 2020). The effect of adding submerged substrates in biofloc systems on the growth of L. vannamei was studied by Olier et al. (2020). Sundaram et al. (2021) studied the effect of natural and artificial periphytic substrates in biofloc systems on both growth and immune response of $L$. vannamei. The present study aimed to understand the water quality and its microbial composition, growth and immune response of $L$. vannamei juveniles reared in substrateintegrated bifloc system over only biofloc system, only substrate system and a control system without biofloc and substrate.

\section{Material and Methods}

\section{Experimental Design}

Sixteen rectangular flat bottom HDPE tanks of $0.6 \mathrm{~m} \times 0.4 \mathrm{~m} \times 0.3 \mathrm{~m}(\mathrm{~L} \times \mathrm{W} \times \mathrm{H})$ size, filled with $50 \mathrm{~L}$ of 10 $\mathrm{g} \mathrm{L}^{-1}$ salinity water were used for the experiment conducted at the wet lab of College of Fishery Science, Muthukur, SPSR Nellore district, Andhra Pradesh, India. Sea water collected from the Krishnapatnam beach $\left(14.2546^{\circ} \mathrm{N}\right.$ and $\left.80.1094^{\circ} \mathrm{E}\right)$ of Bay of Bengal was disinfected with sodium hypochlorite and diluted with freshwater to get salinity of $10 \mathrm{~g} \mathrm{~L}^{-1}$. Healthy L. vannamei juveniles $(3.10 \pm 0.2 \mathrm{~g})$ were procured from a private shrimp farm located at Kogili village, SPSR Nellore district, Andhra Pradesh. The juveniles were acclimatized in rectangular flat bottom fiber glass reinforced plastic (FRP) reservoir tank of one-ton capacity for a period of three weeks prior to stocking in experimental tanks. The experiment consisted of four treatments including control (clear water; C), T1 (only biofloc), T2 (substrate-integrated biofloc) and T3 (only substrate) with zero water exchange. Four replicates were maintained for each treatment. All the tanks were well aerated using 3 aeration pipes with air stones and regulator in each tank through a centralized $0.5 \mathrm{Hp}$ capacity roots air blower. Bamboo mat substrate of $40 \times 28 \mathrm{~cm}$ size was designed as submerged substrates for T2 and T3. Each replicate tank of the treatments T2 and T3 were placed vertically with a bamboo mat substrate. Wheat flour was used as carbon source for the development of biofloc in treatments T1 and T2 in view of its efficacy in production of good quality floc (Azim and little, 2008; Ballester et al., 2010; Anand et al., 2014; Raj Kumar et al., 2015; Kim et al., 2021). The biofloc inoculum was prepared by adding $10 \mathrm{mg}$ of ammonium sulphate and $400 \mathrm{mg}$ of wheat flour as carbohydrate source in glass beakers having one-liter water of $10 \mathrm{~g} \mathrm{~L}^{-1}$ salinity with aeration. After $48 \mathrm{~h}$, the biofloc inoculum from one glass beaker was transferred to each replicate tank of the treatments $\mathrm{T} 1$ and $\mathrm{T} 2$. Immediately after transfer of biofloc inoculum, each of the T1 and T2 treatment tanks were added with 10 ppm ammonium sulphate and $30 \mathrm{ppm}$ of wheat flour for maintaining the biofloc. The acclimatized shrimp $(4.56 \pm 0.13 \mathrm{~g})$ were then stocked in both treatment and control tanks at 10 juveniles per tank. A commercial pellet feed (Charoen Pokphand (CP) India Pvt. Ltd, Chennai, India) with $35.3 \%$ crude protein was fed to shrimp daily at 08:00 Am and 08:00 Pm @ 3.0\% body weight. The details of biochemical composition of the pellet feed and wheat flour (carbon source) are given in Table 1. 
Table 1. Proximate composition of experimental feed and wheat flour (carbon source)

\begin{tabular}{lcc}
\hline Proximate Composition & Experimental Feed & Wheat Flour \\
\hline Protein (\%) & 35.30 & 12.80 \\
Fat (\%) & 6.10 & 1.80 \\
Ash (\%) & 5.05 & 13.30 \\
Fiber (\%) & 4.12 & 1.20 \\
Moisture & 8.72 & 6.72 \\
\hline
\end{tabular}

\section{Maintenance of C: N Ratio}

The $\mathrm{C} / \mathrm{N}$ ratio was manipulated by considering total ammonia nitrogen (TAN) level in treatment tanks by adopting Avinimelech (1999) method. Wheat flour as carbon source was added to the treatment tanks T1 and $\mathrm{T} 2$ for maintaining the $\mathrm{C} / \mathrm{N}$ ratio of $15: 1$ at every threeday interval, after checking the total ammonia nitrogen (TAN) levels. In general, it is assumed that the carbohydrate source contains minimum $50 \%$ carbon, thus taking the microbial growth requirement of $\mathrm{C} / \mathrm{N}$ ratio 15 , about $30 \mathrm{ppm}$ wheat flour was added to reduce TAN concentration by $1 \mathrm{ppm} \mathrm{N}$. The feed used in this study had a calculated $\mathrm{C} / \mathrm{N}$ ratio of 9:1, assuming the feed had $50 \%$ carbon and $5.65 \%$ of nitrogen. The control tanks (C:N-9) were maintained with no supplementation of carbon source. Freshwater was added in all the experimental tanks once a week to make up water loss due to evaporation.

\section{Physico-chemical Water Parameters}

During the study period, water $\mathrm{pH}$ (universal $\mathrm{pH}$ indicator), dissolved oxygen (Aqua check DO test kit, HiMedia Laboratories Pvt. Ltd., Mumbai, India) and temperature (Mercury bulb thermometer) were measured daily at 10:00 Am. Total ammonia nitrogen (TAN) was measured once in every three days at $640 \mathrm{~nm}$; nitrite and- nitrate were measured at weekly intervals at $543 \mathrm{~nm}$ by Spectrophotometric (LMSP-UV 1200, LABMAN Scientific Instruments) method (APHA, 2012). Salinity was measured with portable refractometer (ERMA, RHS-28) once in a week while adding freshwater to compensate evaporation loss.

\section{Qualitative Analysis of Planktonic Organisms in Biofloc and Periphyton}

The biofloc in the water and periphyton developed on a submerged bamboo substrate in treatment tanks were collected for the analysis of planktonic organisms like zooplankton. The samples were suspended in distilled water and fixed in $5 \%$ buffered formalin for few minutes followed by spinning for $3 \mathrm{~min}$ to separate the complex materials in biofloc and periphyton. Then microscopic fauna was observed under binocular microscope (Olympus India Pvt. Ltd., CX21iLEDFS1) and organisms were identified using the taxonomic keys (Brusca and Brusca 2003; Ruppert et al. 2005) and illustrations (APHA, 2012).

\section{Microbial Composition of Biofloc}

At the end of the experiment, total plate count (heterotrophic bacteria), Bacillus, Lactobacillus and Vibrio species were isolated from experimental tanks as per the method described by Kumar et al. (2015) with minor modifications. Microbial populations were collected from each treatment tank by collecting $100 \mathrm{ml}$ of water sample and subjected to centrifugation at $10,000 \mathrm{rpm}$ for $40 \mathrm{sec}$. The pellet formed was then subjected to serial dilutions for fifteen fold using physiological saline. $0.1 \mathrm{ml}$ of dilutions was spread plated on Tryptone soya agar $(1.0 \% \mathrm{w} / \mathrm{v} \mathrm{NaCl})$ for total heterotrophic bacteria (THB) counts. Further, Vibrio, Bacillus and Lactobacillus were isolated on TCBS agar, Bacillus cereus agar and Lactobacillus MRS agar (HiMedia Laboratories Pvt. Ltd., Mumbai, India) respectively. All the inoculated plates were incubated aerobically at $28^{\circ} \mathrm{C}$ for $24-48 \mathrm{~h}$. However, Lactobacillus MRS agar plates were incubated in microaerophilic condition. The incubated plates having 30 to 300 colonies were counted as colony forming units (cfu) per $\mathrm{ml}$.

\section{Growth Performance and Survival Rate}

The experimental shrimp were sampled at weekly intervals and weighed using an electronic balance (A \& D, GR 200) accurate to $0.01 \mathrm{~g}$ for assessment of growth. The shrimps were starved for $24 \mathrm{~h}$ on $49^{\text {th }}$ day, weighed for growth assessment and counted for survival rate. The final growth and survival rate was calculated by using the following formulae (Panigrahi et al., 2017):

Net weight gain (NWG, g) = Final live body weight (g) Initial live body weight (g)

Specific growth rate $(S G R)=100 \times[$ Ln (final body weight $)-$ Ln (initial body weight)] / No. of days of experiment

Feed conversion ratio (FCR) $=$ Total feed consumed (dry weight) / Net wet weight of shrimp

Survival Rate $(\%)=($ Total number of shrimps survived / Total number of shrimps stocked) $\times 100$

\section{Collection of Haemolymph and Serum Samples}

For all the immunological assays, haemolymph were collected from $L$. vannamei at the end of the 
experiment. A total of twelve inter-moult shrimps per treatment i.e., 3 shrimp from each replicate tank collected were anaesthetized using clove oil $\left(50 \mu \mathrm{L} \mathrm{L}^{-1}\right)$. Around $50 \mu \mathrm{l}$ haemolymph was collected from the ventral sinus of each shrimp using anticoagulant $(30 \mathrm{Mm}$ tris-sodium citrate, $388 \mathrm{mM}$ sodium chloride, $10 \mathrm{mM}$ EDTA, $0.12 \mathrm{M}$ glucose, $\mathrm{pH} 7.55)$ coated $1 \mathrm{ml}$ syringe fitted with 26-gauge needle. The collected haemolymph was transferred to $1.5 \mathrm{ml}$ centrifuge tube containing 450 $\mu$ of pre-cooled $\left(4^{\circ} \mathrm{C}\right)$ anticoagulant. The anticoagulant mixed haemolymph samples of each treatment were then pooled into a sterile centrifuge tube and kept on ice for further analysis. Further, haemolymph drawn from the 3 shrimps per replicate of each treatment for serum collection was transferred to anticoagulant free centrifuge tubes and kept undisturbed at $4^{\circ} \mathrm{C}$. After $6 \mathrm{hr}$, the clotted heamolymph tubes were centrifuged at $10,000 \mathrm{rpm}$ for $30 \mathrm{~min}$ followed by collection of supernatant as serum and stored at $-80^{\circ} \mathrm{C}$ until further use.

\section{Estimation of Immune Parameters}

Haemolymph $(150 \mu \mathrm{l})$ collected from 3 shrimps per replicate of each treatment mixed with $1350 \mu \mathrm{l}$ precooled anticoagulant was transferred to a Neubauer haemocytometer and kept under Olympus light microscope (CX21i, LED) at 400x magnification for observing total and differential haemocyte counts. Total haemocyte count (THC) was expressed as total haemocyte cells $\mathrm{ml}^{-1}$ haemolymph. Further, haemocytes were differentiated into granulocytes and agranulocytes (hyaline cells) based on the granular content of the cell (Le Moullac, Klein, Sellos and Van Wormhoudt 1997) were termed as total granulocyte cells $\mathrm{ml}^{-1}\left(\mathrm{TGC} \mathrm{ml}^{-1}\right.$ ) and total agranulocyte cells count $\left(\mathrm{TAC} \mathrm{ml}^{-1}\right)$. The total serum protein content was assessed by Bradford (1976) method. Bradford reagent added to $1 \mu$ serum sample in each tube was well mixed and incubated at room temperature for 20 min followed by measurement of the absorbance at $595 \mathrm{~nm}$ using spectrophotometer (T60, LABINDA). The prophenol oxidase (PO) activity was measured by Cheng and Chen (2000) method, where 25 $\mu \mathrm{l}$ of serum in $150 \mu \mathrm{l}$ of substrate $(5 \mathrm{mM} \mathrm{L}-3,4$, dihydroxy-phenylalanine) made up to $2 \mathrm{ml}$ using tris buffer (50 mM Tris- $\mathrm{HCl}$; $\mathrm{pH}$ 7.5) was incubated for 15 min at room temperature. The colour developed in the reaction wells was measured in ELISA plate reader (POWERWAVE XS, BIOTEK, USA) at $490 \mathrm{~nm}$ against substrate solution as reagent blank and the OD at 490 $\mathrm{nm}$ was expressed as PO activity.

The serum lysozyme activity was analysed by Ellis (1990) turbidimetric method. The standard solution at various concentrations was prepared using chicken egg white lysozyme (Sigma-Aldrich, St. Louis, MO, USA) diluted with $0.04 \mathrm{M}$ phosphate buffer. The Micrococcus lysodeikticus (Sigma-Aldrich, St. Louis, MO, USA) is used as a substrate $\left(0.2 \mathrm{mg} \mathrm{ml} \mathrm{m}^{-1}\right.$ suspension of $M$. lysodeikticus in $200 \mu \mathrm{L}$ of $0.1 \mathrm{M}$ PBS, $\mathrm{pH} 6.5) .10 \mu \mathrm{L}$ of serum with $190 \mu \mathrm{L}$ M. lysodeikticus was added to each well of a 96-well microtiter plate and incubated for 10 $\min$ at $37^{\circ} \mathrm{C}$. The absorbance at $450 \mathrm{~nm}$ was read at 5 $\mathrm{min}$ and then at $15 \mathrm{~min}$ intervals. The lysozyme activity in the sample was calculated using the following formula of the standard curve.

Lysozyme activity (\% inhibition) $=(O D$ of sample at 450 $\mathrm{nm} / \mathrm{OD}$ of positive control at $450 \mathrm{~nm}$ ) $\times 100$

\section{Statistical Analysis}

The experimental results were statistically analyzed using statistical software SPSS version 20 (IBM, 2012). The data on water quality, growth, microbial load and immune parameters were analyzed by one-way analysis of variance (ANOVA) to test difference among the treatments. Statistical significance level was set at $\mathrm{P}<0.05$ and the difference between the treatments means were tested by Duncan's multiple range test.

\section{Results}

\section{Physico-chemical Water Parameters}

The physico-chemical parameters of water were found to be within optimal range for L. vannamei in all the experimental tanks and are presented in Table 2 and Figure 1. Water temperature was not significantly different $(P>0.05)$ among the experimental tanks. However, DO, pH, TAN, Nitrate-N and Nitrite-N showed significant difference $(P<0.05)$, where the experimental tank T2 had significantly lower DO (5.50 $\left.\mathrm{mg} \mathrm{L}^{-1}\right)$ and $\mathrm{pH}$ (7.53) than that of other treatments and control. The TAN, Nitrate- $\mathrm{N}$ and Nitrite- $\mathrm{N}$ concentrations are significantly higher in control $(P<0.05)$ than treatment tanks except Nitrite- $\mathrm{N}$ in T3 tank. Among the treatments significantly higher TAN $\left(0.44 \mathrm{mg} \mathrm{L}^{-1}\right)$, Nitrate- $N$ (1.92 $\left.\mathrm{mg} \mathrm{L}^{-1}\right)$ and Nitrite-N (0.13 $\left.\mathrm{mg} \mathrm{L}^{-1}\right)$ concentrations were recorded in substrate system (T3).

\section{Qualitative Analysis of Planktonic Organisms}

Zooplankton communities were mainly identified in biofloc and periphyton. The bioflocs mainly contained rotifers, copepods, cladocerans, nematodes and ciliated protozoans. The periphyton was composed of rotifers, copepods, ciliates and nematods. Ciliates, rotifers and copepods were dominant groups of microscopic organisms in the all the treatment tanks.

\section{Microbial Load}

The total heterotrophic bacteria, Bacillus $s p$. Lactobacillus sp. and Vibrio sp., counts among the treatment and control groups are given in Table 3 and Figure 2. Significantly higher $(P<0.05)$ bacterial loads were recorded in all treatment tanks than the control group. Among the treatments, $T 2$ had higher $(P<0.05)$ 
Table 2. Water quality parameters (mean \pm SD) of different experimental groups

\begin{tabular}{lcccc}
\hline & & \multicolumn{3}{c}{ Treatments } \\
\cline { 3 - 5 } Parameters & Control & T1 & T2 & T3 \\
\hline Temperature $\left({ }^{\circ} \mathrm{C}\right)$ & $28.79 \pm 0.32^{\mathrm{a}}$ & $28.80 \pm 0.50^{\mathrm{a}}$ & $28.79 \pm 0.46^{\mathrm{a}}$ & $28.80 \pm 0.59^{\mathrm{a}}$ \\
$\mathrm{DO}\left(\mathrm{mg} \mathrm{L}^{-1}\right)$ & $7.64 \pm 0.26^{\mathrm{d}}$ & $6.65 \pm 0.22^{\mathrm{b}}$ & $6.05 \pm 0.14^{\mathrm{a}}$ & $7.28 \pm 0.14^{\mathrm{c}}$ \\
pH & $8.41 \pm 0.13^{\mathrm{d}}$ & $7.93 \pm 0.07^{\mathrm{b}}$ & $7.85 \pm 0.16^{\mathrm{a}}$ & $8.02 \pm 0.09^{\mathrm{c}}$ \\
Total ammonia nitrogen $\left(\mathrm{mg} \mathrm{L}^{-1}\right)$ & $0.49 \pm 0.08^{\mathrm{c}}$ & $0.31 \pm 0.02^{\mathrm{a}}$ & $0.30 \pm 0.04^{\mathrm{a}}$ & $0.44 \pm 0.08^{\mathrm{b}}$ \\
Nitrate-N(mg L-1) & $2.28 \pm 0.11^{\mathrm{d}}$ & $1.60 \pm 0.09^{\mathrm{b}}$ & $0.90 \pm 0.40^{\mathrm{a}}$ & $1.92 \pm 0.20^{\mathrm{c}}$ \\
Nitrite- $\mathrm{N}\left(\mathrm{mg} \mathrm{L}^{-1}\right)$ & $0.14 \pm 0.06^{\mathrm{b}}$ & $0.10 \pm 0.02^{\mathrm{a}}$ & $0.09 \pm 0.03^{\mathrm{a}}$ & $0.13 \pm 0.04^{\mathrm{b}}$ \\
\hline
\end{tabular}

T1, only biofloc; T2, substrate-integrated biofloc; T3, only substrate.

Mean values in the same row with different superscript differ significantly $(P<0.05)$.

(a)

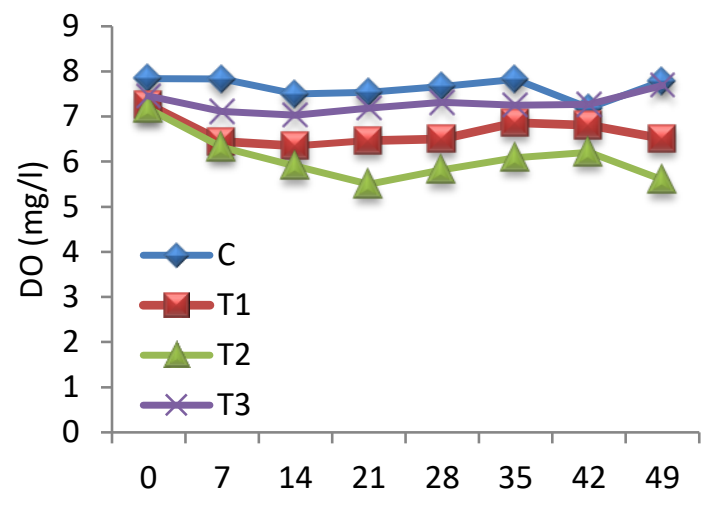

(c)

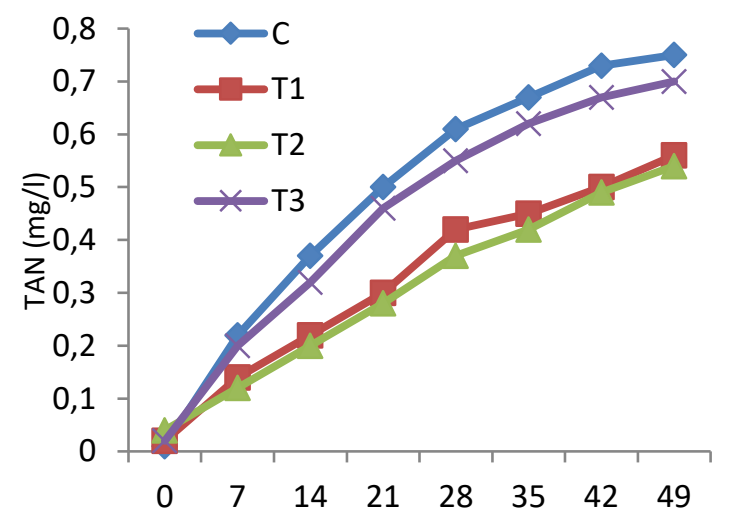

(b)

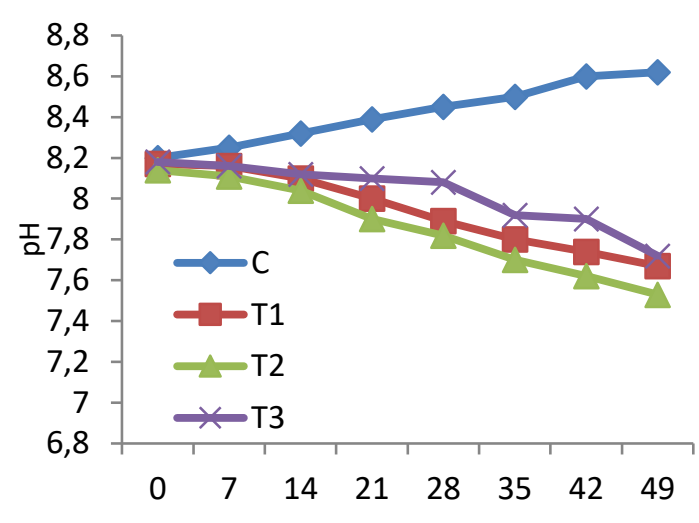

(d)

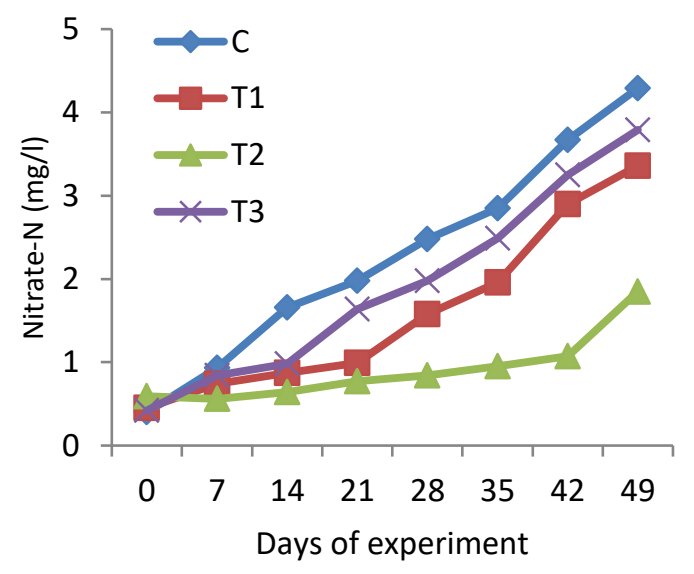

(e)

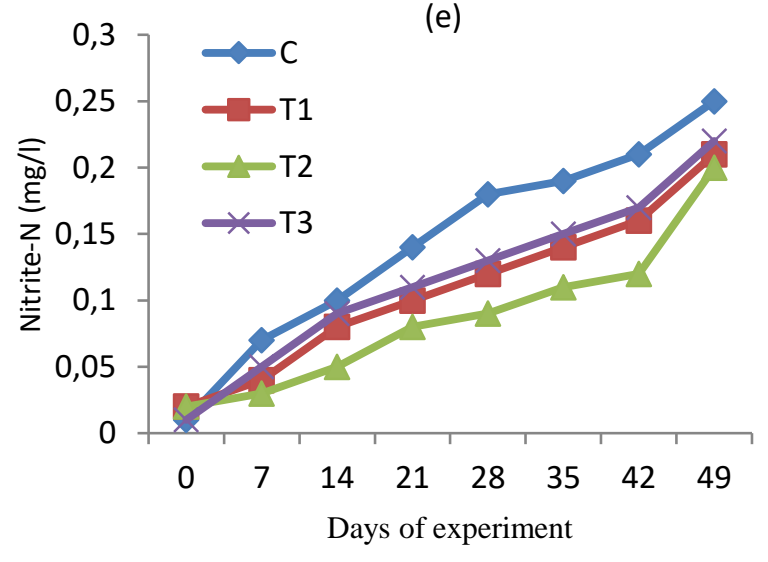

Figure 1. Dissolved oxygen (DO) (a), pH (b), Total ammonia nitrogen (TAN) (c), Nitrate-N (d) and Nitrite-N (e) in different experimental groups. Data represents mean $\pm S D$ of four replicates. 
Table 3. Microbial count (mean $\pm S D$ ) in the experimental tanks

\begin{tabular}{lcccc}
\hline & & \multicolumn{2}{c}{ Treatments } & T3 \\
\cline { 3 - 5 } Parameters & Control & T1 & T2 & $79.60 \pm 13.10^{\mathrm{b}}$ \\
\hline Total Heterotrophic Bacterial Count & $51.50 \pm 3.20^{\mathrm{a}}$ & $146.30 \pm 23.50^{\mathrm{c}}$ & $192.70 \pm 34.50^{\mathrm{d}}$ & $91.67 \pm 18.60^{\mathrm{b}}$ \\
$\left(\mathrm{x} 10^{6} \mathrm{cfu} \mathrm{m}^{-1}\right)$ & $51.79 \pm 5.10^{\mathrm{a}}$ & $127.76 \pm 32.30^{\mathrm{c}}$ & $151.65 \pm 40.40^{\mathrm{d}}$ & $40.85 \pm 22.20^{\mathrm{b}}$ \\
Bacillus Count $\left(\times 10^{4} \mathrm{cfu} \mathrm{ml}^{-1}\right)$ & $30.21 \pm 11.30^{\mathrm{a}}$ & $80.50 \pm 35.65^{\mathrm{c}}$ & $94.80 \pm 47.10^{\mathrm{d}}$ & $36.83 \pm 3.60^{\mathrm{b}}$ \\
Lactobacillus Count $\left(\times 10^{2} \mathrm{cfu} \mathrm{ml}^{-1}\right)$ & $30.16 \pm 2.70^{\mathrm{a}}$ & $47.01 \pm 4.90^{\mathrm{c}}$ & $51.02 \pm 6.50^{\mathrm{d}}$ & 3 \\
Vibrio Count $\left(\times 10^{3} \mathrm{cfu} \mathrm{m}^{-1}\right)$ & & & &
\end{tabular}

$\mathrm{T} 1$, only biofloc; $\mathrm{T} 2$, substrate-integrated biofloc; $\mathrm{T} 3$, only substrate.

Mean values in the same row with different superscript differ significantly $(P<0.05)$. Values expressed in cfu $\mathrm{ml}^{-1}$.

(a)

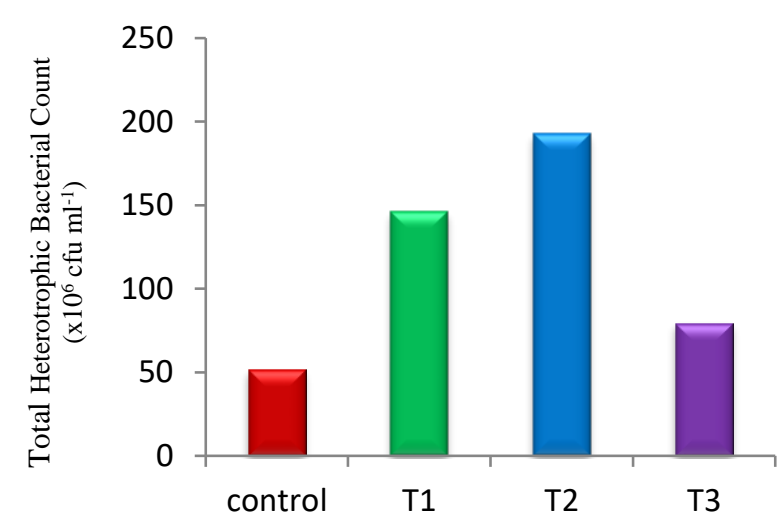

(c)

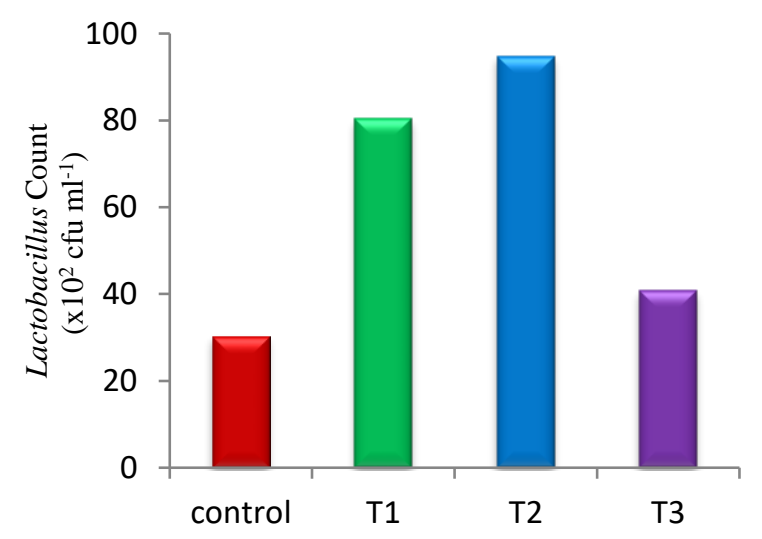

(b)

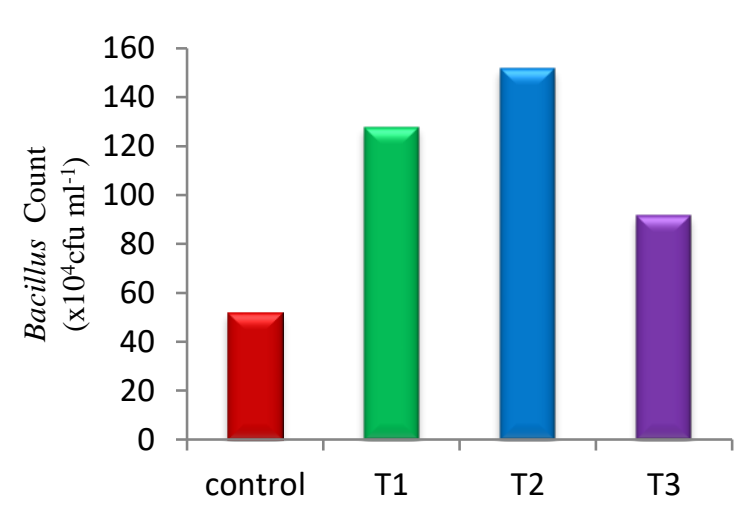

(d)

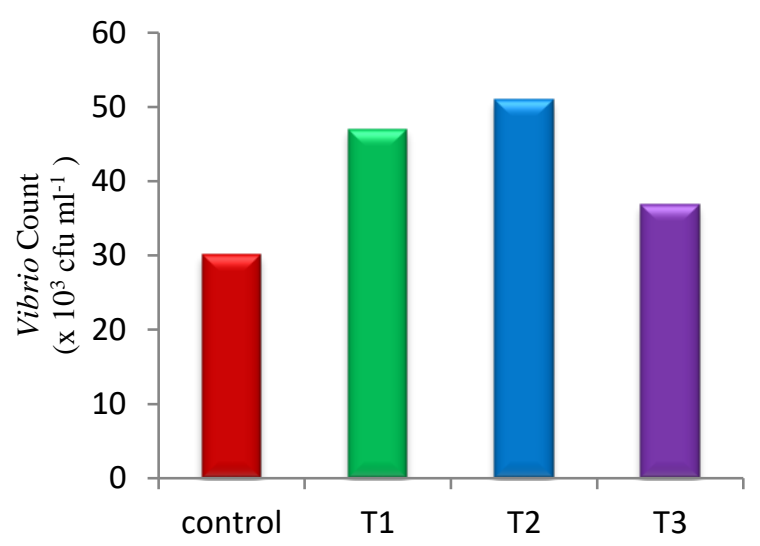

Figure 2. Bacterial count in the experimental groups. (a) Total heterotrophic bacterial count (THB) $\left(\times 10^{6} \mathrm{cfu} \mathrm{m}^{-1}\right)$, (b) Bacillus count $\left(\times 10^{4} \mathrm{cfu} \mathrm{ml}^{-1}\right)$, (c) Lactobacillus count $\left(\times 10^{2} \mathrm{cfu} \mathrm{ml}^{-1}\right)$ and (d) Vibrio count $\left(\times 10^{3} \mathrm{cfu} \mathrm{ml}^{-1}\right)$.

loads of THB $\left(192.70 \pm 34.50 \times 10^{6} \mathrm{cfu} \mathrm{m}^{-1}\right)$, Bacillus $\left(151.65 \pm 40.40 \times 10^{4} \mathrm{cfu} \mathrm{ml}^{-1}\right)$, Lactobacillus $(94.80 \pm$ $\left.47.10 \times 10^{2} \mathrm{cfu} \mathrm{ml}^{-1}\right)$ and Vibrio $\left(51.02 \pm 6.50 \times 10^{3} \mathrm{cfu} \mathrm{ml}^{-}\right.$ $\left.{ }^{1}\right)$ when compared to other two treatments. Among the isolated bacterial communities, Bacillus sp. was the dominant group.

\section{Growth Parameters}

The growth parameters like NWG, SGR, FCR and survival rate was significantly lower $(P<0.05)$ in control group than the treatments. Among the treatments, T2 has significantly better $(P<0.05)$ NWG, SGR and FCR in comparison with the other two treatments. However, survival rate was not significantly different $(P>0.05)$ among all the treatment groups. Growth parameters of L. vannamei recorded in all the experimental groups are shown in Table 4.

\section{Immune Parameters}

In L. vannamei, the total haemocyte count, total hyaline cells and total granular cells, serum protein, phenoloxidase (PO) activity, serum lysozyme activity was significantly higher $(P<0.05)$ in treatment groups than the control (Table 5 and Figure 3). Among the 
treatment groups, T2 had significantly higher $(\mathrm{P}<0.05)$ THC $\left(47.24 \pm 4.49 \times 10^{6}\right.$ cells $\left./ \mathrm{ml}\right)$, hyaline cell count $\left(18.21 \pm 2.22 \times 10^{6}\right.$ cells $\left./ \mathrm{ml}\right)$ and granulocytes count $\left(29.04 \pm 2.89 \times 10^{6}\right.$ cells $\left./ \mathrm{ml}\right)$ than T1 and T3. Similarly, highest serum protein level, phenoloxidase (PO) activity, serum lysozyme activity of shrimp was observed in substrate-integrated biofloc (T2) group than only biofloc (T1) and only substrate (T3) groups.

\section{Discussion}

\section{Water Quality Parameters}

The observed physico-chemical water parameters in all the experimental groups were in suitable ranges for L. vannamei culture (Van et al., 1999; Lin \& Chen, 2003). According to Chen (1985), optimum DO level for the weight increment and survival of shrimp was $5 \mathrm{mg} \mathrm{L}$ ${ }^{1}$. The lowest level of DO recorded in this study in substrate-integrated biofloc treatment (T2) was sufficient $(6.05 \mathrm{ppm})$ for healthy growth of L. vannamei. Immobilization of inorganic nitrogen by heterotrophic bacteria in biofloc, substrate and substrate integratedbiofloc treatments of the present study demanded more DO than the conventional clear water control system as stated by Hargreaves (2006). In the treatment tanks, pH was lower than that of control tanks. The lowest $\mathrm{pH}$ was recorded in substrate-integrated biofloc treatment (T2). This might be due to the high nitrification and respiration rates by microorganisms resulted in increased carbon dioxide $\left(\mathrm{CO}_{2}\right)$ levels in substrateintegrated biofloc (T2) followed by only biofloc and only substrate (T3) treatments (Wasielesky et al., 2006; Zhang et al., 2014; Khanjani et al., 2016, 2019). According to Hargreaves (2013) and Tong et al. (2020) increasing inputs of C: $\mathrm{N}$ ratio between 12 and 15 helps the heterotrophic bacteria for more ammonia $\left(\mathrm{NH}_{3}\right)$ control in biofloc systems. Similarly, in substrate based ponds, periphyton develops on substrate act as habitat for nitrifying bacteria which enhance nitrification keeping ammonia at low level (Anand et al., 2013; Zhang et al., 2014). Earlier studies on water quality in biofloc and substrate systems avoiding water exchange reported lower concentrations of ammonia $\left(\mathrm{NH}_{3}\right)$, nitrite and nitrate (Raj Kumar et al., 2015; Brito et al., 2016; Khanjani et al., 2016; Bossier and Ekasari et al., 2017; Panigrahi et al., 2017 \& 2019; Anand et al., 2019, Khanjani et al., 2019; Khoa et al., 2020; Shilta et al.,
2020; Huang et al., 2021). The levels of TAN and nitrite in substrate-integrated biofloc (T2) and biofloc systems were significantly lower than that of only substrate (T3) and control. This study is in consonance with the observations of Ray et al. (2011), Rajkumar et al. (2015), Luis-Villaseñor et al. (2015) and Olier et al., (2020).

\section{Qualitative Analysis of Plankton in Biofloc and Periphyton}

In the present study, rotifers, copepods, cladocerans, nematodes and ciliated protozoans observed in biofloc are in agreement with the findings of Hargeaves (2013), Panigrahi et al. (2014) and Raj Kumar et al. (2015). Ju et al. (2008) reported that bioflocs consist of $98 \%$ flagellates, $1.5 \%$ rotifer and $0.5 \%$ amoeba. Galvez (2015) recorded 13 genera of zooplankton of rotifera, copepoda, protozoa and cladocera groups in biofloc system in which rotifers remain the most abundant group. Manan et al. (2017) recorded nematodes, gastrotrichs, euplotes, protozoans, rotifers and copepods in the biofloc systems of P. vannamei. Khoa et al. (2020) also recorded diatoms, chlorophytes, protozoa, cyanobacteria, brachionidae, and copepoda in biofloc systems of $L$. vannamei rearing in outdoor culture systems. The periphyton community of the present study composed of rotifers, copepods, ciliates and nematods. Azim et al. (2001) studied periphyton community on bamboo substrates and reported about five genera of zooplankton which includes Rotifera, Copepoda and Cladocera. Anand et al. (2013) also reported that rotifer group dominated among the periphytic communities in the bamboo substrate system followed by nematods and crustaceans. Olier et al. (2020) recorded higher concentrations of diatoms followed by rotifers, nematodes, cladocerans, and ciliated protozoans in the biofloc with Geotextile stripe used as a substrate. In our study, ciliates, rotifers and copepods remain a dominant group in all the treatment tanks. Further, phytoplankton communities were absent in all the treatments since this study was conducted in indoor wet laboratory.

\section{Microbial Community}

In biofloc system, microbial community develops and reaches to a density of $10^{7} \mathrm{cfu} \mathrm{m}^{-1}$ (Buford et al., 2003). Kumar et al. (2015) observed highest mean total

Table 4. Growth parameters of $L$. vannamei (mean $\pm S D)$ in the experimental groups

\begin{tabular}{|c|c|c|c|c|}
\hline \multirow[b]{2}{*}{ Parameters } & \multicolumn{4}{|c|}{ Treatments } \\
\hline & Control & $\mathrm{T} 1$ & $\mathrm{~T} 2$ & T3 \\
\hline NWG (g) & $5.88 \pm 0.34^{a}$ & $9.47 \pm 0.12^{c}$ & $10.38 \pm 0.14^{d}$ & $7.55 \pm 0.36^{b}$ \\
\hline SGR & $1.81 \pm 0.06^{a}$ & $2.32 \pm 0.01^{c}$ & $2.52 \pm 0.02^{d}$ & $1.95 \pm 0.02^{b}$ \\
\hline FCR & $2.05 \pm 0.07^{d}$ & $1.40 \pm 0.08^{b}$ & $1.27 \pm 0.12^{\mathrm{a}}$ & $1.51 \pm 0.02^{c}$ \\
\hline Survival (\%) & $62.50 \pm 0.81^{a}$ & $75.10 \pm 0.57^{b}$ & $77.50 \pm 0.95^{b}$ & $74.60 \pm 0.81^{b}$ \\
\hline
\end{tabular}

T1, only biofloc; T2, substrate-integrated biofloc; T3, only substrate.

Mean values in the same row with different superscript differ significantly $(P<0.05)$. 
Table 5. Immune parameters (mean $\pm S D$ ) of $L$. vannamei in the experimental groups

\begin{tabular}{lcccc}
\hline & \multicolumn{3}{c}{ Treatments } \\
\cline { 2 - 5 } Immune parameters & Control & T1 & T2 & T3 \\
\hline Total Haemocyte count $\left(\times 10^{6}\right)$ & $24.17 \pm 1.78^{\mathrm{a}}$ & $40.53 \pm 3.41^{\mathrm{c}}$ & $47.24 \pm 4.49^{\mathrm{d}}$ & $36.01 \pm 2.30^{\mathrm{b}}$ \\
Total Hyaline cell count $\left(\times 10^{6}\right)$ & $7.67 \pm 0.56^{\mathrm{a}}$ & $16.25 \pm 1.73^{\mathrm{c}}$ & $18.21 \pm 2.22^{\mathrm{d}}$ & $13.32 \pm 1.31^{\mathrm{b}}$ \\
Total Granulocyte count $\left(\times 10^{6}\right)$ & $16.53 \pm 1.68^{\mathrm{a}}$ & $24.28 \pm 2.60^{\mathrm{c}}$ & $29.04 \pm 2.89^{\mathrm{d}}$ & $22.70 \pm 2.43^{\mathrm{b}}$ \\
Serum protein $(\mathrm{mg} / \mathrm{ml})$ & $65.50 \pm 0.03^{\mathrm{a}}$ & $81.60 \pm 0.01^{\mathrm{c}}$ & $82.67 \pm 0.01^{\mathrm{d}}$ & $74.35 \pm 0.04^{\mathrm{b}}$ \\
Phenoloxidase activity (OD at $490 \mathrm{~nm})$ & $0.14 \pm 0.01^{\mathrm{a}}$ & $0.67 \pm 0.02^{\mathrm{c}}$ & $0.73 \pm 0.03^{\mathrm{d}}$ & $0.53 \pm 0.01^{\mathrm{b}}$ \\
Lysozyme activity (\%) & $45.38 \pm 0.01^{\mathrm{a}}$ & $54.54 \pm 0.02^{\mathrm{c}}$ & $56.32 \pm 0.03^{\mathrm{d}}$ & $52.53 \pm 0.01^{\mathrm{b}}$ \\
\hline
\end{tabular}

$\mathrm{T} 1$, only biofloc; $\mathrm{T} 2$, substrate integrated biofloc; $\mathrm{T} 3$, only substrate.

Mean values in the same row with different superscript differ significantly $(P<0.05)$.

(a)

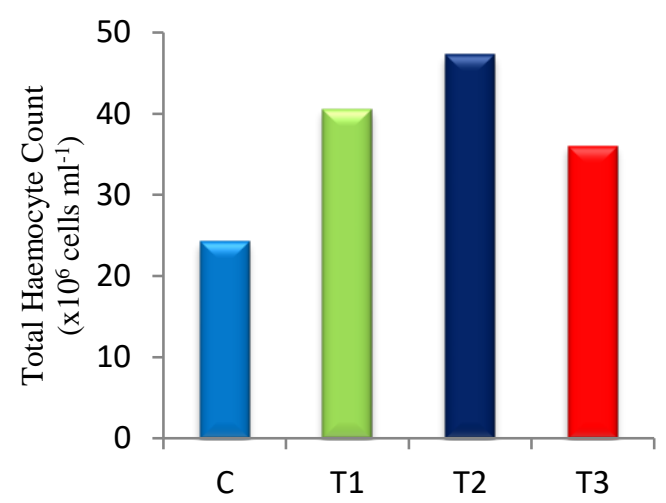

(c)

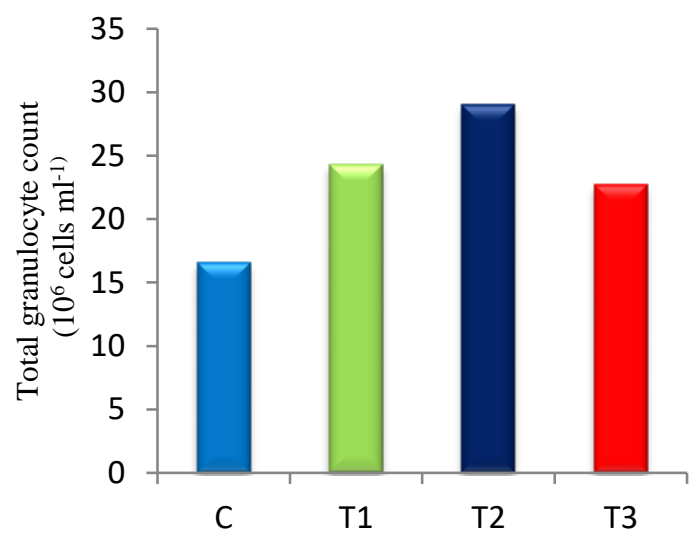

(e)

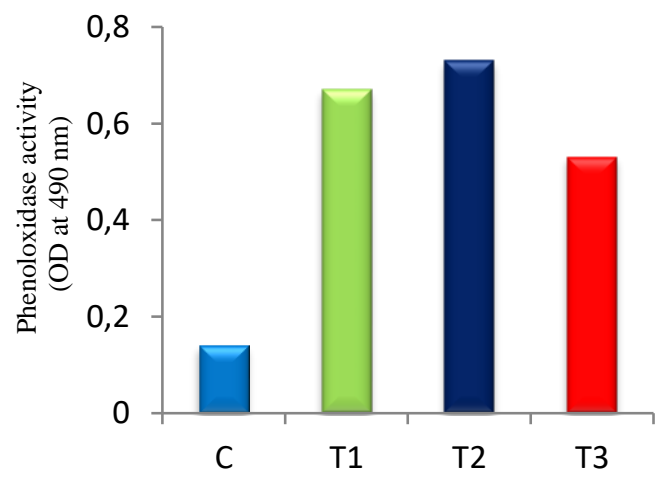

(b)

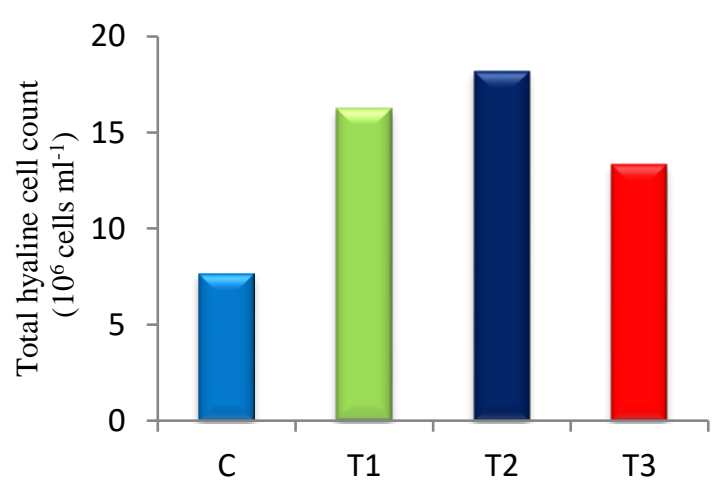

(d)

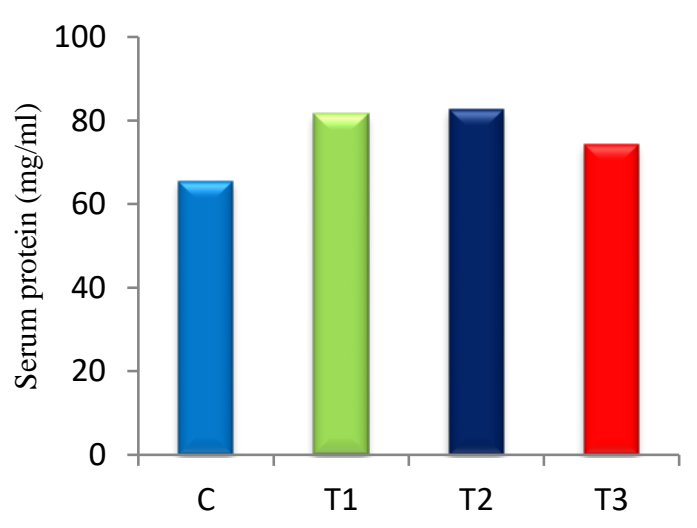

(f)

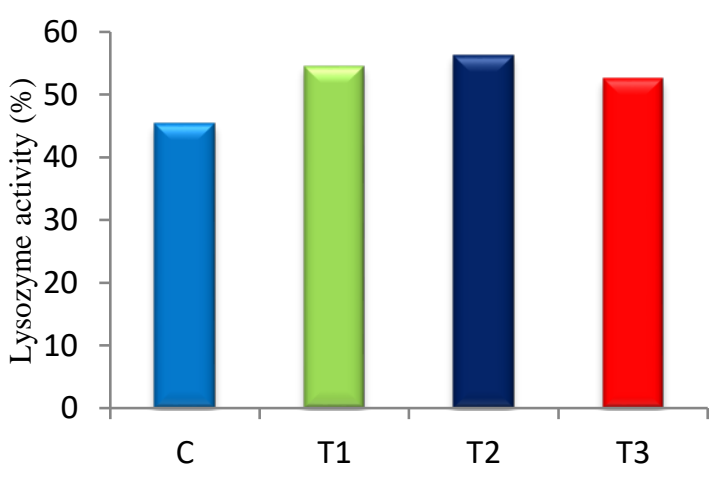

Figure 3. Total haemocyte count $\left(x 10^{6}\right.$ cells ml-1) (a), Total hyaline cell count $\left(x 10^{6}\right.$ cells $\left.\mathrm{ml}^{-1}\right)(\mathrm{b})$, total granulocyte count $\left(\times 10^{6}\right.$ cells $\left.\mathrm{ml}^{-1}\right)(\mathrm{c})$, serum protein $(\mathrm{mg} / \mathrm{ml})(\mathrm{d})$, phenoloxidase activity $(\mathrm{OD}$ at $490 \mathrm{~nm})(\mathrm{e})$ and lysozyme activity (\%) (f) in $P$. vannamei juveniles reared in only biofloc, only substrate, substrate-integrated biofloc and clear water control (C) systems. 
bacterial count in bioflocs generated from molasses with Bacillus being the most dominant bacterial group followed by Vibrio and Lactobacillus. Similarly, Panigrahi et al. (2019) also reported that carbohydrate supplementation systems significantly increasing the THB count $(82.9 \pm 4.4 \%)$ in biofloc system when compared with control group. Recently, Khoa et al. (2020) found significantly high THB and Vibrio loads in biofloc treatment tanks when compared with control. Furthermore, Sundaram et al. (2020) recorded significantly high THB loads in substrate integrated biofloc systems than clear water control system. In our study, all the treatment tanks were observed with significantly higher counts of THB, Bacillus, Lactobacillus and Vibrio loads than that of control tanks. Substrateintegrated biofloc treatment (T2) has recorded with significantly higher THB, Bacillus, Lactobacillus and Vibrio counts than the only biofloc and only substrate treatments which might be due to the development of heterotrophic bacteria in higher abundance, both in the form of flocs and biofilm in $\mathrm{T} 2$.

\section{Growth Parameters}

Enhanced growth performance, survival and better FCR was observed in L. vannamei (Wasielesky et al., 2006; Becerra-Dorame et al., 2012; Xu \& Pan, 2012; Emerenciano et al., 2013; Krummenauer et al., 2014; Rajkumar et al., 2015; Luis-villasen̈or et al., 2015; Panigrahi et al., 2017 \& 2019; Abbaszadeh et al., 2019; Khanjani et al., 2016 \& 2019; Khoa et al., 2020; Tong et al., 2020; Huang et al., 2021; Silva et al., 2021), P. monodon (Kumar et al., 2015), Fenneropenaeus indicus (Effendy et al., 2016) reared in the biofloc systems than that of conventional systems. Similarly, the rearing of $P$. monodon (Arnold et al., 2006; Anand et al., 2013; Anand et al., 2019), Farfantepenaeus paulensis (Ballester et al., 2007), Macrobrachium rosenbergii (Uddin, 2007; Shilta et al., 2020) and L. vannamei (Zhang et al., 2014) in artificial submerged substrate systems has shown increased production and survivability. Sundaram et al. (2021) recorded highest weight gain of L. vannamei reared in submerged substrate-integrated biofloc systems. In the present study also, the growth performance and survival rate of $L$. vannamei was significantly higher in treatment groups than that of control. On the other hand, substrate-integrated biofloc system performed better than systems with the only biofloc and only substrate. Integration of substrates in biofloc system has recorded better growth performance and survivability in M. rosenbergii (Assaduzzaman et al., 2010), L. vannamei (Becerra-Dórame et al., 2012; Schveitzer et al., 2013; Ferreira et al., 2015; Olier et al., 2020) than that of biofloc systems alone. The present study results corroborate with the findings of above studies that shows more positive effect of submerged substrates when integrated in biofloc system on production of $L$. vannamei juvenile than the systems in which these techniques are used independently.

\section{Immunological Parameters}

Haemolymph parameters are mostly used to monitor the physiological condition, nutritional quality and status of immune systems in crustaceans exposed to various stressors (Matozzo et al., 2011; PorchasCornejo et al., 2011). The circulating haemocyte count of crustaceans in terms of both increase in quantity and quality and proPO activity indicated enhanced immune status in crustaceans and hence disease resistance (Rodriguwz \& Le Moullac, 2000; Chiu et al., 2007). The higher serum protein levels were observed in $P$. monodon juveniles fed on biofloc incorporated diets (Anand, 2012) and as well reared in biofloc systems (Kumar et al., 2015). Similarly, higher serum protein levels in both haemolymph and muscle of L. vannamei were observed in submerged substrate based culture systems (Audilo-Naranjo et al., 2012). Sundaram et al. (2021) also reported significantly high serum protein levels of $L$. vannamei reared in substrate integrated biofloc systems than that of clear water control system. On the other hand, lysozymes are initial defenders against bacteria and remain as hall mark of non-specific immunity in crustaceans (Vazquez et al., 2009). In our study, substrate-integrated biofloc, only biofloc and only substrate treatments recorded with better immune response in $L$. vannamei in terms of total haemocytes, hyaline cells, granulocyte count, PO activity, serum protein and serum lysozyme activity when compared to control shrimp. An elevated level of THC has been reported after feeding shrimp with dietary supplements like probiotics (Rengpipat et al., 2000; Li et al., 2009; Abdollahi-Arpanahi et al., 2018), $\beta$-glucan (Lopez et al., 2003; Neto \& Nunes, 2015), macroalgae and $\beta$-carotene supplemented diets (Supamattaya et al., 2005; Niu et al., 2014). Similarly, increased haemocyte count was reported in L. vannamei (Xu \& Pan, 2013; Panigrahi et al., 2017, 2018 \& 2019; Abbaszadeh et al., 2019; Tong et al., 2020;), P. monodon (Kumar et al., 2015) and $P$. indicus (Panigrahi et al., 2020) in biofloc based systems. Further, Zhang et al. (2010) reported that, microbial biofilms in periphyton, developed over submerged substrates, enhanced the non-specific immunity factors in penaeid shrimp. Shrimps evidently consume microbial floc in situ in biofloc systems (Crab et al., 2012), that increases THC and PO activity in vannamei biofloc systems (Kim et al., 2014), indicating higher expression levels of proPO1, proPO2 and PPAE1 genes. Similarly, higher PO activity was observed in L. vannamei (Ekasari et al., 2014; Panigrahi et al., 2017, 2018 \& 2019), P. monodon (Kumar et al., 2015) and $P$. indicus (Panigrahi et al., 2020) when grown in biofloc systems than in clear water system. Sundaram et al. (2021) also reported high PO activity, superoxide dismutase assay of $L$. vannamei, reared in substrate-integrated biofloc systems than that of clear water system. Significantly higher lysozyme activity was observed in GIFT stain of Oreochromis niloticus (Long et al., 2015) and Labeo rohita (Ahmad et al., 2016) reared in biofloc culture systems. Vega et al. 
(2006) reported active antibacterial activity of $L$. vannamei recombinant lysozyme (c-lyz) against Vibrio alginolyticus, $V$. parahaemolyticus and $V$. cholera. In the present study, among the treatment groups shrimp grown in substrate-integrated biofloc system elicited significantly better THC, hyaline cell count, granulocyte, PO activity, serum protein and lysozyme activity over only biofloc or only substrate systems. This improvement might be attributed to the consumption of large quantity of bacteria (Bacillus and Lactobacillus) associated with bioflocs and substrates by the shrimp that has probably released immune-stimulatory substances in the intestinal tract and could significantly enhanced the immune status in L. vannamei juveniles in substrate-integrated biofloc system.

\section{Conclusion}

This study reveals that the substrate-integrated biofloc based system is more suitable for vannamei farming than the systems with only biofloc or only substrate for better production and immune status of shrimp with enhanced water quality. Hence, initiatives are to be taken to develop several nutritional procedures like biofloc and periphyton based systems which can maximize the contribution of higher quality in situ food in the same culture system besides maintaining water quality and enhanced immune status in $L$. vannamei. This would help in expanding zero-water exchange biosecured culture systems for vannamei shrimp to achieve maximum production. These are the results of a small scale indoor laboratory experiment. So, further studies are required to understand the suitability and economic viability of biofloc system, substrate system and substrate-integrated biofloc system at shrimp farm level on commercial scale.

\section{Ethical Statement}

All applicable national guidelines for the care and use of animals were followed by the authors.

\section{Funding Information}

This research study received funding from Sri Vekateswara Veterinary University (SVVU), (Head of Account: 110413-stipends to PG students, SVVU), Andhra Pradesh, India.

\section{Author Contribution}

FirstAuthor: Conceptualization, Writing -review and editing, Data Curation, Formal Analysis, Investigation, Methodology, Visualization and Writing original draft.

Corresponding Author: Funding Acquisition, Project Administration, Resources, Supervision, Writing -review and editing.
All authors have made substantial contributions to each step of experimental study. The idea for this study was given by major guide Dr. Tambireddy Neeraja to Chethurajupalli Lavanya. The experiment was designed and performed under the guidance of T. Neeraja for carrying out the Master of Fisheries Science (MFSc) research work. This article was prepared by the first author and edited by second author.

\section{Conflict of Interest}

The authors declare no conflict of interest.

\section{Acknowledgements}

The authors acknowledge the gratitude to the authorities of Sri Vekateswara Veterinary University (SVVU), Andhra Pradesh, India for the financial support in carrying out of post graduate (MFSc) research work of the first author. We express our sincere gratitude to former Vice Chancellor Dr. Y. Haribabu and the former Dean of fisheries faculty Dr. T.V. Ramana, SVVU for moral support extended during the study period. The first author is also highly thankful to SVVU authorities for providing fellowship during her MFSc (Aqutic Animal Health management) study at College of Fishery Science, Muthukur, Andhra Pradesh, India.

\section{References}

Abbaszadeh A., Yavari V., Hoseini S. J., Nafisi M., \& Torfi Mozanzadeh M. (2019). Effects of different carbon sources and dietary protein levels in a biofloc system on growth performance, immune response against white spot syndrome virus infection and cathepsin $\mathrm{L}$ gene expression of Litopenaeus vannamei. Aquaculture Research, 50, 1162-1176. https://doi.org/10.1111/are.13991

Abreu, P. C., Ballester, E. L. C., Odebrecht, C., Wasielesky Jr. W., Cavalli, R. O., Granéli, W., \& Anésio, A. M. (2007). Importance of biofilm as food source for shrimp (Farfantepenaeus paulensis) evaluated by stable isotopes (d13C and d15N). Experimental Marine Biology and Ecology, 347, 88-96. https://doi.org/10.1016/j.jembe.2007.03.012

Abdollahi-Arpanahia, D., Soltanib, E., Jafaryana, H., Soltanic, H., Naderi-Samanic, M., \& Isidro Campa-Córdova, A. (2018). Efficacy of two commercial and indigenous probiotics, Bacillus subtilis and Bacillus licheniformis on growth performance, immuno-physiology and resistance response of juvenile white shrimp (Litopenaeus vannamei). Aquaculture, 496, 43-49. https://doi.org/10.1016/j.aquaculture.2018.06.082

Ahmad. I. H., Verma, A. K., Babitha Rani, A. M., Rathore, G., Neelam Saharan \& Gora, A. H. (2016): Growth, nonspecific immunity and disease resistance of Labeo rohita against Aeromonas hydrophila in biofloc systems using different carbon sources. Aquaculture Research, 457, 6167. https://doi.org/10.1016/j.aquaculture.2016.02.011

Anand P. S. S., Kohli M. P. S., Kumar, S., Sundaray J. K., Dam Roy S., Venkateshwarlu G., Sinha A., \& Pailan G. H. (2014). Effect of dietary supplementation of biofloc on 
growth performance and digestive enzyme activities in Penaeus monodon. Aquaculture, 418, 108-115. https://doi.org/10.1016/j.aquaculture.2013.09.051

Anand, P. S. S., Sujeet Kumar, A. Panigrahi, T. K. Ghoshal, J. Syama Dayal, G. Biswas, J. K. Sundaray, D. De, R. Ananda Raja, A. D. Deo, S. M. Pillai \& Ravichandran, P. (2013). Effects of C:N ratio and substrate integration on periphyton biomass, microbial dynamics and growth of Penaeus monodon juveniles. Aquculture Internatinaol, 21 , 511-524. https://doi.org/10.1007/s10499-0129585-6

Anand P. S. S. (2012): Effects of dietary supplementation by periphyton biomass and biofloc on growth and immunophysiological aspects of juvenile penaeus monodon fabricius (1798), M.F.Sc, Thesis submitted to Central Institute of Fisheries Education, Mumbai, India, pp.222.

Anand, P. S., Balasubramanian, C. P., Christina, L., Kumar, S., Biswas, G., De, D., Ghoshal, T. K., \& Vijayan, K. K. (2019). Substrate based black tiger shrimp, Penaeus monodon culture: stocking density, aeration and their effect on growth performance, water quality and periphyton development. Aquaculture, 507, 411-418. https://doi.org/10.1016/j.aquaculture.2013.09.051

Anguilera-Rivera, D., Prieto-Davo, A., Escslante, K., Chavez, C., Cuzon, G., \& Gaxiola G. (2014). Probiotic effect of floc on vibrios in the pacific white shrimp. Aquaculture, 283, 8994. https://doi.org/10.1016/j.aquaculture.2014.01.008

Arnold, S. J., Sellars, M. J., Crocos, P. J., \& Coman, G. J. (2005). Response of juvenile brown tiger shrimp (Penaeus esculentus) to intensive culture conditions in a flow through tank system with three-dimensional artificial substrate. Aquaculture, 246, 231-238.

https://doi.org/10.1016/j.aquaculture.2005.01.020

Arnold S. J., Sellars M. J., Crocos P. J., \& Coman G. J. (2006). Intensive production of juvenile tiger shrimp Penaeus monodon: an evaluation of stocking density and artificial substrates. Aquaculture, 261, 890-896. https://doi.org/10.1016/j.aquaculture.2006.07.036

APHA, (2012). Association, American Public Health, Association, American Water Works and Federation, Water Environment). Standard Methods for the Examination of Water and Wastewater, 22nd ed, Washington, D.C.

Asaduzzaman, M., Rahman, M. M., Azim, M. E., Islam, M. A., Wahab, M. A., Verdegem, M. C. J., \& Verreth, J. A. J. (2010). Effects of $\mathrm{C} / \mathrm{N}$ ratio and substrate addition on natural food communities in freshwater prawn monoculture ponds. Aquaculture, 306, 127-136. http://dx.doi.org/10.1016/j.aquaculture.2010.05.035

Audelo-Naranjo, J. M., Martinez-Cordova, L. R., \& Voltolina, D. (2010). Nitrogen budget in intensive cultures of Litopenaeus vannamei in mesocosms, with zero water exchange and artificial substrates. Revista de Biología Marina y Oceanografía, 45, 519-524.

Audelo-Naranjo, J. M., Martinez-Cordova, L. R., GomezJimenez, S., \& Voltolina, D. (2012). Intensive culture of Litopenaeus vannamei without water exchange and with artificial substrate cultivate intensive de Litopenaeus vannamei sin recambio de agua y con un substrate artificial. Hidrobiologica, 22(1), 1-7.

Avnimelech, Y. (1999). Carbon/nitrogen ratio as a control element in aquaculture systems. Aquaculture, 176, 227235.

Azim M. E., Wahab M. A, van Dam A. A., Beveridge M. C. M., \& Verdegem M. C. J. (2001). The potential of periphyton- based culture of two Indian major carps, rohu Labeo rohita (Hamilton) and gonia Labeo gonius (Linnaeus). Aquaculture research, 32, 209-216. https://doi.org/10.1046/j.1365-2109.2001.00549.x

Azim M. E., \& Wahab M. A. (2005). Periphyton-based pond polyculture. In: Periphyton -Ecology, exploitation and management. CABI Publishing, Wallingford, 207-222.

Azim M. E., Verdegem M. C. J., Khatoon H., Wahab M. A., Van Dam A. A., \& Beveridge M. C. M. (2002). A comparison of fertilization, feeding and three periphyton substrates for increasing fish production in freshwater pond aquaculture in Bangladesh. Aquaculture, 212, 227-243. https://doi.org/10.1016/S0044-8486(02)00093-5

Azim M. E., \& Little D. C. (2008). The biofloc technology (BFT) in indoor tanks: water quality, biofloc composition, and growth and welfare of Nile tilapia (Oreochromis niloticus). Aquaculture, 283, 29-35.

http://dx.doi.org/10.1016/j.aquaculture.2008.06.036

Ballester E. L. C., Wasielesky W. Jr, Cavall R. O., \& Abreu P. C. (2007). Nursery of the pink shrimp Farfantepenaeus paulensis in cages with artificial substrates: biofilm composition and shrimp performance. Aquaculture, 269, 355-362.

https://doi.org/10.1016/j.aquaculture.2007.04.003

Ballester, E. L. C., Abreu, P. C., Cavalli, R. O., Emerenciano, M. Abreu, L., \& Wasielesky, W., (2010). Effect of practical diets with different protein levels on the performance of Farfantepenaeus paulensis juveniles nursed in a zero exchange suspended microbial flocs intensive system. Aquaculture nutrition, 16, 163-172. https://doi.org/10.1111/j.1365-2095.2009.00648.x

Becerra-Dorame, Marcel Martinez-Porchas, Luis R MartinezCordova, Martha E. Rivas-Vega, Jose A. Lopez-Elias, Marco \& A. Porchas-Cornejo (2012). Production Response and Digestive Enzymatic Activity of the Pacific White Shrimp Litopenaeus vannamei (Boone, 1931) Intensively Pre grown in Microbial Heterotrophic and Autotrophic-based Systems. The Science World Journal, 1-6. https://doi.org/10.1100/2012/723654

Bender J., Lee R., Sheppard M., Brinkley K., Philips P., Yeboah Y., \& Wah R. C. (2004). A waste effluent treatment system based on microbial mats for black sea bass Centropristis striata recycled-water mariculture. Aquaculture Engineering, 31, 73-82. https://doi.org/10.1016/j.aquaeng.2004.02.001

Bossier P., \& Ekasari J. (2017). Biofloc technology application in aquaculture to support sustainable development goals. Microbial Biotechnology, 10, 1012-1016. https://doi.org/10.1111/1751-7915.12836

Bradford M. A. (1976). A rapid and sensitive method for quantitation of microgram quantities of protein utilizing the principle of protein-dye binding. Animal Bioscience, 72, 248-254. https://doi.org/10.1016/0003-2697(76)90527-3

Brito L. O., Chagas A. M., da Silva E. P, Soares R. B, Severi W., \& Galvez A. O. (2016). Water quality, Vibrio density and growth of Pacific white shrimp Litopenaeus vannamei (B oone) in an integrated biofloc system with red seaweed Gracilaria birdiae (Greville). Aquaculture Research, 47: 940-950. https://doi.org/10.1111/are.12552

Brusca, R., \& Brusca G. J. (2003). Invertebrates, 2nd edn. Sinauer Associates, Sunderland Massachusetts.

Burford M. A., Thompson P. J., \& McIntosh R. P. (2004). The contribution of flocculated material to shrimp (Litopenaeus vannamei) nutrition in a high-intensity, 
zero-exchange system. Aquaculture, 232, 525-537. https://doi.org/10.1016/S0044-8486(03)00541-6

Burford, M. A., Thompson, P. J., Mclntosh, R. P., Bauman, R. H., \& Pearson, D.C. (2003). Nutrient and microbial dynamics in high-intensity, zero water exchange shrimp ponds in Belize. Aquaculture, 219, 393-411. https://doi.org/10.1016/S0044-8486(02)00575-6

Chen, H. C. (1985). Water quality criteria for farming the grass shrimp, Penaeus monodon. First international conference on the culture of penaeids prawn/shrimp. Aquaculture department. SEAFDEC.165.

Chiu, C. H., Guru, Y. K. Lui, C. H., Pan, T. M., \& Cheng, W. (2007). Immune responses and gene expression in white shrimp, Litopenaeus vannamei, induced by Lactobacillus plantarum. Fish and Shellfish Immunology, 23, 364-377. https://doi.org/10.1016/j.fsi.2006.11.010

Cheng, J., \& Chen, C. (2000). Effects of pH, temperature and salinity on immune parameters of the freshwater prawn Macrobrachium rosenbergii, Fish Shellfish Immunology, 10 (4), 387-391.

https:// doi.org/10.1006/fsim.2000.0264

Crab, R., Chielens B., Wille M., Bossier P., \& Verstraete W. (2010). The effect of different carbon sources on the nutritional value of bioflocs, a feed for Macrobrachium rosenbergii postlarvae. Aquaculture Research, 41, 559567. https://doi.org/10.1111/j.1365-2109.2009.02353.x

Crab, R., Defoirdt T., Bossier P., \& Verstraete W. (2012). Biofloc technology in aquaculture: beneficial effects and future challenges. Aquaculture, 357, 351-356. https://doi.org/10.1016/j.aquaculture.2012.04.046

De Schryver, P. D., Crab, R., Defoirdt, T., Boon, N., \& Verstraete, W. (2008). The basics of bio-flocs technology: The added value for aquaculture. Aquaculture, 277, 125 137. https://doi.org/10.1016/j.aquaculture.2008.02.019

Dodds, W. K. (2003). The role of periphyton in phosphorus retention in shallow freshwater aquatic systems. Journal of Physiology, 39, 840-849. https://doi.org/10.1046/j.1529-8817.2003.02081.x

Effendy, Samy A., Deen, I., \& Chithambaran, S. (2016). Semi intensive and semi biofloc methods for the culture of Indian white prawn, Fenneropenaeus indicus in highdensity polyethylene liner ponds. Hayti Bioscience, 23, 106-110. https://doi.org/10.1016/j.hjb.2016.06.004

Ekasari, J., Azhar, M. H., Enang H., Surawidjaja, Sri Nuryati, De Schryver, P., \& Bossier, P. (2014). Immune response and disease resistance of shrimp fed biofloc grown on different carbon sources. Fish and Shellfish Immunology, 41, 332-339. https://doi.org/10.1016/j.fsi.2014.09.004

Ellis, A. E. (1990). Lysozyme assays. In: Stolen J. S, Fletcher T. C, Anderson D. P, Roberson B S, van Muiswinkel W.B (eds). Techniques in Fish Immunology. Fair Haven: SOS Publications, 101-103.

Emerenciano, M., Ballester, E. L. C, Cavalli, R. O., \& Wasielesky, W. (2012). Biofloc technology application as a food source in a limited water exchange nursery system for Pink shrimp Farfantepenaeus brasiliensis (Latreille, 1817). Aquaculture Research, 43, 447-457. https://doi.org/10.1111/j.1365-2109.2011.02848.x

Emerenciano, M., Gaxiola, G., \& Cuzon, G. (2013). Biofloc Technology (BFT): A review for aquaculture application and animal food industry. In: Matovic M. D. (ed) Biomass now-cultivation and utilization. InTech, Rijeka, 301-328. https://dx.doi.org/10.5772/53902

FAO, (2012): The state of world fisheries and aquaculture. ISBN 978-92-5-107225-1. FAO Fisheries Department, Rome.
Fernandes D. S., C., Ballester, E., Monserrat, J., Geracitano, L., Wasielesky J. W., \& Abreu, P. C. (2008). Contribution of microorganisms to the biofilm nutritional quality: protein and lipid contents. Aquaculture Nutrition, 14, 507-514.

https://doi.org/10.1111/j.1365-2095.2007.00556.x

Ferreira, M. H., Lara, G., Wasielesky, W., \& Abreu, P. C. (2015). Biofilm versus biofloc: Are artificial substrates for biofilm production necessary in the BFT system? Aquaculture. International, 24 (4), 921-930. https://doi.org/10.1007/s10499-015-9961-0

Galvez A. O. (2015). Plankton communities in shrimp monoculture, integrated biofloc system. Global Aquaculture Advocate MAY/ JUN 2015

Hargreaves, J. A., (2006). Photosynthetic suspended-growth systems in aquaculture. Aquaculture engineering, 34 344-363.

https://doi.org/10.1016/j.aquaeng.2005.08.009

Hargreaves, J. A. (2013). Biofloc production systems for aquaculture. Southern Regional Aquaculture Centre Publication, 4503.

Haslun, J., Correia, E, Strychar, Morris, T., \& Samocha, T. (2012). Characterization of bioflocs in a no water exchange super-intensive sysem for the production of food size pacific white shrimp Litopenaeus vannamei. International journal of aquaculture, 2(6), 29-38. https://doi.org/10.5376/ija.2012. 02.0006

Huang, H. H., Liao, H. M., Lei, Y. J., \& Yang, P. H. (2021). Effects of different carbon sources on growth performance of Litopenaeus vannamei and water quality in the biofloc system in low salinity. Aquaculture, 737239. https://doi.org/10.1016/j.aquaculture.2021.737239

Ju Z., Forster, I., Conquest, L., \& Dominy, W. (2008). Enhanced growth effects on shrimp (Litopenaeus vannamei) from inclusion of whole shrimp floc or floc fractions to a formulated diet. Aquaculture nutrition, 14, 533-543. https://doi.org/10.1111/j.1365-2095.2007.00559.x

Kamilya D., Debbarma M., Pal P., Kheti B., Sarkar S., \& Singh S. T. (2017). Biofloc technology application in indoor culture of Labeo rohita (Hamilton, 1822) fingerlings: the effects on inorganic nitrogen control, growth and immunity. Chemosphere, 182, 8-14. https://doi.org/10.1016/j.chemosphere.2017.05.021

Khanjani, M., Sajjadi, M., Alizadeh, M., \& Sourinejad, I. (2016). Study on nursery growth performance of Pacific white shrimp (Litopenaeus vannamei Boone, 1931) under different feeding levels in zero water exchange system. Iranian Journal of Fisheries Science. 15(4), 1465-1484. http://hdl.handle.net/1834/37709

Khanjani, M., Sajjadi, M., Alizadeh, M., \& Sourinejad, I. (2019). Rearing of the Pacific white shrimp, Litopenaeus vannamei in a biofloc system: The effects of different food sources and salinity levels. Aquaculture Nutrition, 1-10. https://doi.org/10.1111/anu.12994

Khanjani, M. H., \& Sharifinia, M. (2020). Biofloc technology as a promising tool to improve aquaculture production. Reviews in aquaculture. 1-15. https://doi.org/10.1111/raq.12412

Khoa, T. N. D., Tao, C. T., Khanh, L. V., \& Hai, T. N. (2020). Superintensive culture of white leg shrimp (Litopenaeus vannamei) in outdoor biofloc systems with different sunlight exposure levels: Emphasis on commercial applications. Aquaculture, 524, 735277. https://doi.org/10.1016/j.aquaculture.2020.735277 
Kim, S. K., Pang, Z., Seo, H. C., Cho, Y. R., Samocha, T., \& Jang, I. K. (2014). Effect of bioflocs on growth and immune activity of Pacific white shrimp, Litopenaeus vannamei postlarvae. Aquaculture Research, 45, 362-371. https://doi.org/10.1111/are.12319

Kim, Y. S., Kim, S. E., Jinkim, S., Jung, H. K., Park, R., JaeJeon, P., HyungKim, HaKang, J., \& Hokim, K. (2021). Effects of wheat flour and culture period on bacterial community composition in digestive tracts of Litopenaeus vannamei and rearing water in biofloc aquaculture system. Aquaculture, 531(30), 735908 https://doi.org/10.1016/j.aquaculture.2020.735908

Krummenauer, D., Poersch, L., Romano, L. A., Lara, G. R., Encarnação, P., \& Wasielesky, Jr, W. (2014). The effect of probiotics in a Litopenaeus vannamei biofloc culture system infected with Vibrio parahaemolyticus. Journal of applied Aquaculture. 26, 370-379. https://doi.org/10.1080/10454438.2014.965575

Kuhn D. D., Lawrence A. L., Boardman G. D., Patnaik, S., Marsh, L., \& Flick, G. J. (2010). Evaluation of two types of bioflocs derived from biological treatment of fish effluent as feed ingredients for Pacific White Shrimp, Litopenaeus vannamei. Aquaculture, 303, 28-33.

https://doi.org/10.1016/j.aquaculture.2010.03.001

Kumar. S., Anand P. S. S., De Deo., Ghoshal, T. K., \& Jithendran, K. P. (2014). Effects of Biofloc and Mat Based Substrates on Microbial Composition, Growth Performance and Immune Responses in Black Tiger Shrimp Penaeus monodon. In: The $10^{\text {th }}$ Indian fisheries and aquaculture forum (1OIFAF) NBFGRR, Lucknow, India, 12-15. (Abstract) 344.

Kumar, S., Anand, P. S. S., De Deo, Ghoshal, T., Sundaray, K., Ponniah, A.G., Jithendran, K. P., Raja, R. A., Biswas, G., \& Lalitha, N. (2015). Effect of biofloc under different carbon sources and protein levels on water quality, growth performance and immune responses in black tiger shrimp Penaeus monodon (Fabricus, 1978). Aquaculture Research, 1-15. https://doi.org/10.1111/are.12958

Langis, R., Proulx, D., de la Noeue, J., \& Couture, P. (1988). Effects of a bacterial biofilm on intensive Daphnia culture. Aquaculture Engineering, 7, 21-38. https://doi.org/10.1016/0144-8609(88)90036-2

Le Moullac, G., Klein, B., Sellos, D., \& Van Wormhoudt, A., (1997). Adaptation of trypsin, chymotrypsin and $\alpha$ amylase to casein level and protein source in Penaeus vannamei (Crustacea Decapoda). Export Marine Biology and Ecology, 208, 107-125. https://doi.org/10.1016/\$0022-0981(96)02671-8

Li, Tan, B., \& Mai, K. (2009). Dietary Probiotic Bacillus OJ and iso-malto oligosaccharides influence the intestine microbial populations, immune responses and resistance to white spot syndrome virus in shrimp. Aquaculture, 291, 35-40.

https://doi.org/10.1016/j.aquaculture.2009.03.005

Lin Y. C., \& Chen J. C. (2003). Acute toxicity of nitrite on Litopenaeus vannamei (Boone) juveniles at different salinity levels. Aquaculture, 224, 193-201. https://doi.org/10.1016/S0044-8486(03)00220-5

Long, L., Yang, J., Li, Y., Guan, C., \& Wu, F. (2015). Effect of biofloc technology on growth, digestive enzyme activity, hematology, and immune response of genetically improved farmed tilapia (Oreochromis niloticus), Aquaculture, 448.

https://doi.org/10.1016/j.aquaculture.2015.05.017
Lopez, N., Cuzon, G., Gaxiola, G., Taboada, G., Valenzuela, M. Pascual, C., Sanchez, A., \& Rosas, C. (2003). Physiological, nutritional and immunological role of dietary $\beta-1-3$ glucan and ascorbic acid monophosphate in Litopenaeus vannamei juveniles. Aquaculture, 224, 223-243. https://doi.org/10.1016/S0044-8486(03)00214-X

Luis-Villaseñor, Voltolina, D., Audelo-Naranjo, J. M., María R. Pacheco-Marges, Herrera-Espericueta, V, E., \& RomeroBeltrán, E. (2015). Effects of biofloc promotion on water quality, growth, biomass yield and heterotrophic community in Litopenaeus vannamei (Boone, 1931) experimental intensive culture. Italian Journal of Animal Science. 14, 332-337. https://doi.org/10.4081/ijas.2015.3726

Manan, H., Julia, H. Z. M., Azman Kasan, N., Suratman, S., \& Ikhwanuddin, M., (2017). Identification of biofloc microscopic composition as the natural bioremediation in zero water exchange of Pacific white shrimp, Penaeus vannamei, culture in closed hatchery system. Applied Water Science, 7, 2437-2446. https://doi.org/10.1007/s13201-016-0421-4

Martinez-Porchas., Luis, R., \& Martinez-Cordova (2012). World Aquaculture: environmental impacts and troubleshooting alternatives. The Science World Journal. Article ID 389623, 9 p. https://doi.org/10.1100/2012/389623

Matozzo, V., Gallo, C., \& Marin, M. G. (2011). Effects of temperature on cellular and biochemical parameters in the crab Carcinus aestuarii (Crustacean, Decapoda). Marine Environmental Research, 71, 351-356. https://doi.org/10.1016/j.marenvres.2011.04.001

Moss, M., Moss, M. R., Arce, S. M., Lightner, D. V., \& Lotz, J. M. (2012). The role of selective breeding and biosecurity in the prevention of disease in penaeid shrimp aquaculture. Journal of Invertebrate Pathology, 10 (2), 247-250. https://doi.org/10.1016/j.jip.2012.01.013

Neto, H. S., \& Nunes, A. J. P. (2015). Performance and immunological resistance of Litopenaeus vannamei fed a $\beta-1,3 / 1,6$-glucan-supplemented diet after per os challenge with the Infectious myonecrosis virus (IMNV). Revista Brasileira de Zootecnia, 44(5), 165-173. http://dx.doi.org/10.1590/S1806-92902015000500001

Niu, J., Wen, H., Chun-HouLi, JianLiu Y., Tian, X., Chen, X., Huang, Z., \& Lin, H. Z. (2014). Comparison effect of dietary astaxanthin and $\beta$-carotene in the presence and absence of cholesterol supplementation on growth performance, antioxidant capacity and gene expression of Penaeus monodon under normoxia and hypoxia condition. Aquaculture, 422-423(20), 8-17. https://doi.org/10.1016/j.aquaculture.2013.11.013

Olier, B. S., Jiovani S. B. T., Giovanni Lemos de M., Marcel M. P., \& Maurício G. C. E. (2020). Does vertical substrate could influence the dietary protein level and zootechnical performance of the Pacific white shrimp Litopenaeus vannamei reared in a biofloc system. Aquaculture International, 1-25. https://doi.org/10.1007/s10499-020-00521-4

Panigrahi, A., Sundaram, Ravichandran, P., \& Gopal, C. (2014). Microbial Soup-Eco based approach for shrimp culture and management. ENVIS Newsletter on Microorganisms and Environment Management 12(2).

http://krishi.icar.gov.in/jspui/handle/123456789/12139

Panigrahi, A. M. Sundaram, J. Jebha, J. Syamadayal, S. K. Otta, T. Bhuvaneswari, R. Saraswathy, P. S. Shyne Anand, D. Rajababu, C. Saranya, Gopal, C., \& P. Ravichandran 
(2017). Biofloc based nutrient dense culture system for nursery and grow-out farming of Pacific white shrimp Penaeus vannamei Boone, 1931. Indian Journal of fisheries, 64, 22-32. http://doi.org/10.21077/ijf.2017.64

Panigrahi, A., Sundaram, M., Chakrapani, S., Rajasekar, S., Dayal, J. S., \& Gopal, C. (2018). Effect of carbon and nitrogen ratio $(\mathrm{C}: \mathrm{N})$ manipulation on the production performance and immunity of Pacific white shrimp Litopenaeus vannamei (Boone, 1931) in a biofloc-based rearing system. Aquaculture Research, 50, 29-41. http://doi.org/10.1111/are.13857

Panigrahia, A., Sundaram M., Saranya C., Satish Kumar R., Syama Dayal J., Saraswathy R., Otta S. K., Shyne Anand P. S., Nila Rekha, P., \& Gopal C. (2019). Influence of differential protein levels of feed on production performance and immune response of pacific white leg shrimp in a biofloc-based system. Aquaculture, 503, 118-127.

https://doi.org/10.1016/j.aquaculture.2018.12.036

Panigrahi, A., Das, R. R., Sivakumar, M. R., A. Saravanan, C. Saranya, N. S. Sudheer, K. P. Kumaraguru Vasagam, P. Mahalakshmi, Kannappan, S., \& G. Gopikrishna (2020). Bio-augmentation of heterotrophic bacteria in biofloc system improves growth, survival, and immunity of Indian white shrimp Penaeus indicus. Fish and shell fish Immunology, 98, 477-487.

https://doi.org/10.1016/j.fsi.2020.01.021

Porchas-Cornejio, M. A., Martinez-Cordova, L. R., RamosTrujillo, L., Hernandez-Lopez, Martinez-Porchas, J., \& M., Mendoza-Cano, F. (2011). Effect of promoted natural feed on the production, nutritional and immunological parameters of Litopenaeus vannamei (Boon, 1931) semiintensively farmed. Aquaculture Nutrition, 17, 622-628. https://doi.org/10.1111/j.1365-2095.2010.00809.x

Raj Kumar, M., Pandey, P.K., Aravind, R., Vennila, A., Bharti, V., \& Purushothaman, C. S., (2015). Effect of different biofloc system on water quality, biofloc composition and growth performance in Litopenaeus vannamei (Boone, 1931). Aquaculture Research, 1-13.

https://doi.org/10.1111/are.12792

Ramesh, M. R., Shankar, K. M., Mohan, C.V., \& Varghese, T. J. (1999). Comparison of three plant substrates for enhancing carp growth through bacterial biofilm. Aquaculture Engineering, 19, 119-131. https://doi.org/10.1016/S0144-8609(98)00046-6

Ray, A. J., Lewis B. L., Browdy, C. L., \& Leffler J. W. (2010). Suspended solids removal to improve shrimp (Litopenaeus vannamei) production and an evaluation of a plant-based feed in minimal-exchange, super intensive culture systems. Aquaculture, 299, 89-98. https://doi.org/10.1016/j.aquaculture.2009.11.021

Ray A. J., Dillon, K. S., \& Lotz, J. M. (2011). Water quality dynamics and shrimp (Litopenaeus vannamei) production in intensive, mesohaline culture systems with two levels of biofloc management. Aquaculture Engineering, 45, 127-136. https://doi.org/10.1016/j.aquaeng.2011.09.001

Rengpipat, S., Rukpratanporn, S., Piyatiratitivorakul, S., \& Menasaveta, P. (2000). Immunity enhancement in black tiger shrimp (Penaeus monodon) by a probiont bacterium (Bacillus S11). Aquaculture, 191, 271-288. https://doi.org/10.1016/S0044-8486(00)00440-3

Ringo E., Jose R. E. O., Vecino L. G., Wadsworth, S., \& Song, S. (2012). Use of immunostimulants and nucleotides in aquaculture: A Review Marine Science Research
Development, 2, 1-22.

https:// doi.org/10.4172/2155-9910.1000104

Rodriguwz, J., \& Le Moullac (2000). State of the art of immunological tools and health control of penaeids shrimp. Aquaculture, 191, 109-119.

https://doi.org/10.1016/S0044-8486(00)00421-X

Ruppert E. E., Fox R. S., \& Barnes R. D. (2005). Zoologia dos invertebrados. Roca, São Paulo

Samocha, T. M., Lawrence, A. L., Collins, C. A., Castille, F. L., Bray, W. A., Davies C. J., Lee, P. G., \& Wood G. F. (2004). Production of the Pacific white shrimp, Litopenaeus vannamei, in high-density greenhouse-enclosed raceways using low salinity groundwater. Journal of Applied Aquaculture, 15, 1-19.

https://doi.org/10.1300/J028v15n03_01

Schveitzer, R., Arantes, R., Costodio, P. F. S., Carlos M. Do Espirito Santo, Arana, L. V., Seiffert, W. Q., \& Andreatta, E. R. (2013). Effect of different biofloc levels on microbial activity, water quality and performance of Litopenaeus vannamei in a tank system operated with no water exchange. Aquaculture Engineering, 56, 59-70. https://doi.org/10.1016/j.aquaeng.2013.04.006

Shilta, M. T., Christina L., Lalrinsanga, P. L., \& Bindu P. (2020). Biofilm developed on plant substrates enhances growth and survival of post larvae of Macrobrachium rosenbergii. Fisheries Technology, 57, 88 - 97. http://eprints.cmfri.org.in/id/eprint/14276

Silva, D. A., de Lima, P. C. M., da Silva, A. E. M., Oliveira Filho, P. R. C., da Silva, S. M. B. C., Gálvez, A. O., \& Brito, L. V. (2021). Effects of adding rotifers on the water quality, plankton composition and growth of Pacific white shrimp, Litopenaeus vannamei juvenile, when cultured with biofloc technology. Aquaculture Research, 52(9), 4380-4393. https://doi.org/10.1111/are.15276

Smith V. J., Brown J. H., \& Hauton C. (2003). Immunostimulation in crustaceans: does it really protect against infection. Fish and Shellfish Immunology, 15, 7190. https://doi.org/10.1016/S1050-4648(02)00140-7

Sundaram, M., Sivakumar, R. M., Saranya, C., Krishna, A., Anand P. S. S., Christina, L., Antony, J., \& Panigrahi, A. (2021). The effect of natural and artificial periphytic substrates with biofloc system on shrimp Penaeus vannamei (Boone 1931) culture: growth and immune response. Aquaculture International, 29, 651-668. https://doi.org/10.1007/s10499-021-00646-0

Supamattaya, K., Kiriratnikom, S., Boonyaratpalin, M., \& Borowitzka L. (2005). Effect of a Dunaliella extract on growth performance, health condition, immune response and disease resistance in black tiger shrimp (Penaeus monodon). Aquaculture, 248, 207-216. https://doi.org/10.1016/j.aquaculture.2005.04.014

Tong, R., Chen, W., Luqing P., \& Zhang, K. (2020). Effects of feeding level and $\mathrm{C} / \mathrm{N}$ ratio on water quality, growth performance, immune and antioxidant status of Litopenaeus vannamei in zero -water exchange bioflocsbased outdoor soil culture ponds. Fish and shellfish immunology, 101, 126-134. https://doi.org/10.1016/j.fsi.2020.03.051

Thompson, F. L., Abreu, P. C., \& Wasielesky W. (2002). Importance of biofilm for water quality and nourishment in intensive shrimp culture. Aquaculture, 203, 263-278. https://doi.org/10.1016/S0044-8486(01)00642-1

Uddin M. S. (2007). Mixed culture of tilapia (Oreochromis niloticus) and freshwater prawn (Macrobrachium rosenbergii) in periphyton-based ponds. Ph. D, Thesis, 
Wageningen University, the Netherlands.

Van Wyk, P., \& Scarpa, J. (1999). Water quality and management In: Farming marine shrimp in recirculating freshwater systems. Florida Department of Agriculture and Consumer Servieces. Tallahassee, 128-138.

Vazquez, L., Alpuche, J., Maldonado, G., Agundis, C., Pereyramorales \& Zenteno, E. (2009). Review: Immunity mechanisms in crustaceans. Research, 15, 179. https://doi.org/10.1177\%2F1753425909102876

Vega, E., Garcida-Galaz, A., Diaz-Clnco, M. E., \& Sotelo-Mundo, R. R. (2006). White shrimp recombinant lysozyme has antibacterial activity against gram negative bacteria: Vibrio alginolyticus, Vibrio parahaemolyticus and Vibrio cholera. Fish and Shellfish Immunology, 20, 405-408. https://doi.org/10.1016/j.fsi.2005.06.005

Verlencar, X. N., \& Desai, S. (2004). Phytoplankton identification manual. National Institute of Oceanography. http://drs.nio.org/drs/handle/2264/97

Vinatea, L., Galvez, A. O., Browdy, C. L., Stokes, A., Venero, J., Haveman, J., Lewis, B. L., Lawson, A., Shuler, A., \& Leffler, J. W. (2010). Photosynthesis, water respiration and growth performance of Litopenaeus vannamei in a super-intensive raceway culture with zero water exchange: Interaction of water quality variables. Aquaculture Engineering, 42, 17-24. https://doi.org/10.1016/j.aquaeng.2009.09.001

Wasielesky, W. Jr., Atwood, H., Stokes, A., \& Browdy, C. L. (2006). Effect of natural production in a zero exchange suspended microbial floc based super-intensive culture system for white shrimp Litopenaeus vannamei. Aquaculture, 258, 396-403. https://doi.org/10.1016/j.aquaculture.2006.04.030

Xu, W. J., \& Pan, L. Q. (2013). Enhancement of immune response and antioxidant status of Litopenaeus vannamei juvenile in biofloc-based culture tanks manipulating high $\mathrm{C} / \mathrm{N}$ ratio of feed input. Aquaculture, 412, 117-124. https://doi.org/10.1016/j.aquaculture.2013.07.017

Xu, W. J., Pan, L. Q., Zhao, D. H., \& Huang, J. (2012). Preliminary investigation into the contribution of bioflocs on protein nutrition of Litopenaeus vannamei fed with different dietary protein levels in zero-water exchange culture tanks. Aquaculture, 350, 147-153. https://doi.org/10.1016/j.aquaculture.2012.04.003

Xu, W. J., \& Pan, L. Q. (2012). Effects of bioflocs on growth performance, digestive enzyme activity and body composition of juvenile Litopenaeus vannamei in zerowater exchange tanks manipulating $\mathrm{C} / \mathrm{N}$ ratio in feed. Aquaculture, 57, 147-152. https://doi.org/10.1016/j.aquaculture.2012.05.022

Xu, W. J., Pan, L. Q., Sun, X. H., \& Huang, J. (2012a). Effects of bioflocs on water quality, and survival, growth and digestive enzyme activities of Litopenaeus vannamei (Boone) in zero-water exchange culture tanks. Aquaculture Research, 356-357, 147-152. https://doi.org/10.1111/j.1365-2109.2012.03115.x

Zhao, P., Huang, J., Wang, X. H., Song, X. L., Yang, C. H., Zhang, X. G., \& Wang, G. C. (2012). The application of bioflocs technology in high-intensive, zero exchange farming systems of Marsupenaeus japonicas. Aquaculture, 354, 97-106.

https://doi.org/10.1016/j.aquaculture.2012.03.034

Zhang, B., Lin, W., Wang, Y., \& Xu, R. (2010). Effects of artificial substrates on growth, spatial distribution and nonspecific immunity factors of Litopenaeus vannamei in intensive culture. Turkish Journal of Fisheries and Aquatic Science, 10, 491-497. https://doi.org/ 10.4194/trjfas.2010.0408

Zhang, B. (2011): Influence of the artificial substrates on the attachment behavior of Litopenaeus vannamei in the intensive culture condition. International Journal of Animal and Veterinary Advances, 3 (1), 37-43.

Zhang, J., Chen, L., Dong, H., Duan, Y., Li, Z., Wen, G., Chen, J., Feng, Z., Xu, W., \& Xie, J., (2014). Artificial substrates in zero-water-exchange culture system regulate the rearing performance of Pacific white shrimp Litopenaeus vannamei (Boone, 1931) under the winter indoor condition. Aquaculture Research, 1-10. https://doi.org/10.1111/are.12473

Zhao, P., Huang, J., Wang, X. H., Song, X. L., Yang, C. H., Zhang, X. G., \& Wang, G. C. (2012). The application of bioflocs technology in high-intensive, zero exchange farming systems of Marsupenaeus japonicas. Aquaculture, 354, 97-106.

https://doi.org/10.1016/j.aquaculture.2012.03.034 